\title{
ZMIANY W GOSPODARCE FINANSOWEJ SPÓŁDZIELNI SOCJALNEJ W Polsce
}

\section{Wprowadzenie}

Spółdzielnia socjalna została wprowadzona do polskiego porządku prawnego w 2006 r. jako podmiot realizujący zadania z zakresu reintegracji społecznej i zawodowej ${ }^{1}$. Stanowić miała przedłużenie systemu ograniczania wykluczenia społecznego w związku z niewielką skutecznością narzędzi stosowanych dotychczas. Ustawodawca powoływał się na włoskie rozwiązana prawne, które funkcjonowały z dużym powodzeniem od końca lat 70. ubiegłego wieku, jednak adaptując ten mechanizm wspierania osób defaworyzowanych do polskich rozwiązań prawnych zdefiniował spółdzielnię socjalną poprzez pryzmat spółdzielni pracy, gdzie przedmiotem działalności podmiotu jest prowadzenie wspólnego przedsiębiorstwa w oparciu o osobistą pracę jej członków. Taka modyfikacja sprawiła, iż spółdzielnie socjalne na początku swojej działalności były rozpoznawalne, a tym samym akceptowane przez innych przedsiębiorców działających na lokalnym rynku. Tym samym spółdzielnię socjalną włączono do systemu wspierania osób wykluczonych. Do niej miały trafiać osoby opuszczające Centra Integracji Społecznej, które nie były jeszcze gotowe do wyjścia na otwarty rynek pracy. Spółdzielnie socjalne dały im natomiast szansę na doskonalenie swoich umiejętności, co w przypadku osób z niepełnosprawnością, opuszczających zakłady karne, wychodzących z bezdom-

* Dr, Powiślańska Szkoła Wyższa w Kwidzynie; e-mail: andrzejmichalik66@wp.pl.

1 Art. 2 ustawy z dnia 27 kwietnia 2006 r. o spółdzielniach socjalnych, Dz. U. z 2006 r. Nr 94, poz. 651 (dalej: u.s.s.2006). 
ności czy bezrobotnych i korzystających z zatrudnienia socjalnego, miało istotne znaczenie dla ich przyszłego rozwoju ${ }^{2}$.

$\mathrm{Na}$ samym początku liczba spółdzielni socjalnych systematycznie rosła. Było to przede wszystkim spowodowane licznymi programami finansowanymi ze środków Unii Europejskiej kierowanymi do osób wykluczonych, które mogły założyć spółdzielnie socjalne. Z czasem jednak pojawił się problem związany ze stawianiem spółdzielni w stan likwidacji. Było to spowodowane brakiem systemu wparcia dla spółdzielni socjalnych oraz niemożnością zaangażowania w ich tworzenie osób prawnych. W konsekwencji fundusze, którymi dysponowały na starcie te podmioty w krótkim okresie czasu przekazywane były z funduszu zasobowego na pokrycie istniejących zobowiązań ${ }^{3}$. Tym samym niezbędne były zmiany udoskonalające system wsparcia dla tego typu podmiotów. Pod koniec 2009 r. pojawiły się rozwiązania pozwalające na tworzenie spółdzielni socjalnych przez osoby prawne oraz na dopuszczenie stosowania klauzul społecznych przy zamówieniach publicznych ${ }^{4}$. Uelastyczniono również system dofinansowywania działalności i pozyskiwania środków z funduszy publicznych ${ }^{5}$. Mimo postulowanych zmian nie udało się wprowadzić modyfikacji w zakresie gospodarki finansowej podmiotu. Nadal nadwyżka finansowa wypracowana przez spółdzielnie socjalne, mocą uchwały Walnego Zgromadzenia, była dzielona na trzy istniejące w spółdzielni fundusze: zasobowy, celowy i inwestycyjny. W konsekwencji spółdzielnia dysponująca wolnymi środkami zobligowana była prawnie do realizacji celów społecznych oraz zyskała możliwość realizacji zadań z zakresu pożytku publicznego na rzecz społeczności lokalnej. Ustawa dookreślając

2 Zob. C. Miżejewski, Przemiany prawa spółdzielczości socjalnej w Polsce, „Problemy Polityki Społecznej: Studia i Dyskusje" 2013, nr 1, s. 43.

3 Zob. J. Duraj, Przestanki powstania spótdzielni socjalnych w Polsce i zróżnicowanie przedmiotu ich działania, „Acta Universitatis Lodziensis” 2012, nr 272, s. 10.

4 Poprzez klauzule społeczne należy rozumieć takie zmiany w ustawie Prawo zamówień publicznych, które umożliwiały priorytetowe traktowanie spółdzielni socjalnych. Zgodnie z art. 29 cytowanej wyżej ustawy możliwe stało się dopuszczanie do zamówienia jedynie tych podmiotów, które spełniały określone wymogi w zakresie zatrudnienia osób defaworyzowanych, co nie wykluczało udziału w takich postępowaniach innych przedsiębiorców pod warunkiem spełnienia nakreślonych wytycznych zatrudnienia osób wykluczonych, zob. C. Miżejewski, Przemiany prawa spótdzielczości..., s. 57.

5 Szerzej na ten temat, zob. ustawa z dnia 7 maja 2009 r. o zmianie ustawy o spółdzielniach socjalnych oraz o zmianie niektórych innych ustaw, Dz. U. z 2009 r. Nr 91, poz. 742 (dalej: u.s.s.2009). 
górny pułap podziału nie pozostawiała władzom spółdzielni swobody decyzji. Zgodnie z wytycznymi na fundusz zasobowy i ten związany z realizacją celów stawianych przed spółdzielnią socjalną przeznaczano nie mniej niż 40\% nadwyżki bilansowej, zaś na inwestycyjny pozostawiając jedynie $20 \%$ środków pochodzących z nadwyżki bilansowej. Dodatkowo nadwyżka bilansowa nie mogła być dzielona pomiędzy członków spółdzielni. Ograniczało to pozyskiwanie przez nich dodatkowych dochodów, z drugiej zaś strony dawało szansę na rozwijanie spółdzielni i realizowanie założonych przez nią celów społecznych i gospodarczych, co ma istotne znaczenie zwłaszcza na początku ich działalności ${ }^{6}$.

W ostatnim czasie wprowadzono istotne zmiany, jeśli chodzi o gospodarkę finansową spółdzielni socjalnej. Ustawodawca zdecydował się na przebudowę systemu gospodarowania środkami organizacji. Przede wszystkim zmianie uległy górne granice przekazywania nadwyżki bilansowej na konkretny fundusz. W przypadku funduszu zasobowego podmiot zobowiązany jest przekazać na ten cel nie mniej niż $20 \%$ nadwyżki bilansowej, zaś w przypadku funduszu fakultatywnego realizującego cele społeczne nie mniej niż 30\% nadwyżki podlegającej podziałowi ${ }^{7}$. Usunięto z gospodarki finansowej spółdzielni fundusz inwestycyjny, który został zastąpiony funduszem wzajemnościowym mającym na celu pobudzić spółdzielnie do współpracy w ramach konsorcjum spółdzielczego ${ }^{8}$.

Wskazać należy, iż część z tych funduszy ma charakter obligatoryjny, inne zaś fakultatywny. Fundusz zasobowy stanowiący podstawę działalności spółdzielni pochodzi z wpłat członków spółdzielni oraz ze środków publicznych (Fundusz Pracy), jak i unijnych czy prywatnych definiowanych, jako nadwyżka bilansowa. Przeznaczony jest on na pokrywanie strat przy likwidacji spółdzielni i jest obowiązkowy dla każdego podmiotu spółdzielczości socjalnej. Analogicznie jest w przypadku funduszu celowego i inwestycyjnego (zniesionego od 2017 r.). Zwłaszcza ten pierwszy pełni istotną rolę $\mathrm{w}$ realizacji celów społecznych nakładanych

6 Zob. J. Ziobrowska, Spółdzielnie socjalne jako przykład rozwoju przedsiębiorczości spoŁecznej w Polsce, [w:] B. Kryk (red.), Gospodarka regionalna i międzynarodowa, t. 2, seria: Zeszyty Naukowe. Studia i Prace Wydziału Nauk Ekonomicznych i Zarządzania - Uniwersytet Szczeciński, nr 46, Szczecin 2016, s. 334.

7 Zob. art. 1 pkt 8 ustawy z dnia 15 grudnia 2017 r. o zmianie ustawy o spółdzielniach socjalnych oraz niektórych innych ustaw, Dz. U. z 2017 r. poz. 2494 (dalej: u.s.s.2017).

8 Zob. M. Kawa, W. Kuźniar, Spótdzielnie socjalne jako instytucje odpowiedzialności spoŁecznej, „Nierówności Społeczne a Wzrost Gospodarczy” 2016, z. 4, s. 394. 
przez ustawę, związanych z reintegracją społeczną i zawodową członków i pracowników spółdzielni.

Podobnie jak inne spółdzielnie, również spółdzielnia socjalna może tworzyć fundusze fakultatywne. Podstawą ich utworzenia mogą być zapisy statutu lub uchwała Walnego Zgromadzenia. Mogą być one wykorzystane nie tylko do powołania funduszu wzajemnościowego związanego z przystąpieniem do konsorcjum spółdzielczego, ale także do realizacji celów społecznych. Nie wszystkie z nich muszą być sprecyzowane w statucie, bowiem Walne Zgromadzenie, jako najwyższy organ spółdzielni decydujący o gospodarczych i społecznych kierunkach jej rozwoju, może zdecydować o wyznaczeniu celu jego istnienia. Ich charakter jest zróżnicowany i może mieć zarówno charakter gospodarczy i dotyczyć realizacji konkretnego projektu związanego z rozwojem ekonomicznym spółdzielni socjalnej, podnoszącego konkurencyjność jednostki, jak i realizację działalności pożytku publicznego mającego charakter celu społecznego.

Fundusze fakultatywne mogą być tworzone również na pokrycie strat. Ma to miejsce zwłaszcza w przypadku spółdzielni socjalnych, które dysponują $\mathrm{w}$ danej chwili znaczącym kapitałem, a w przyszłości mają podjąć inwestycje związane z podwyższonym ryzykiem.

Z uwagi na kategorię osób będących członkami spółdzielni socjalnych, część z nich decyduje się powołać do życia również Zakładowy Fundusz Świadczeń Socjalnych. Ma on za zadanie finansowanie wsparcia na rzecz pracowników zatrudnionych w oparciu o spółdzielczą umowę o pracę. Dotyczy to pomocy socjalnej, wypoczynku, działalności rekreacyjnej oraz wsparcia w zakresie kulturalnego rozwoju członków i ich rodzin. Pomoc przyznawana jest w oparciu o odrębny regulamin zawierający wytyczne, co do dochodów oraz sytuacji materialnej pracowników.

Poza działalnością ekonomiczną oraz związaną z reintegracją społeczną i zawodową, spółdzielnia socjalna może realizować także dodatkowe zadania na rzecz wspólnoty lokalnej. W tym celu władze spółdzielni mogą powołać fundusz społeczno-kulturalny przeznaczony na realizację lokalnych projektów integrujących członków spółdzielni z otoczeniem. Ma to pośrednio również ekonomiczny charakter, bowiem wzrost rozpoznawalności spółdzielni socjalnej przekłada się na wzrost dochodów podmiotu.

Zmiany w zakresie kategorii funduszy, którymi może dysponować spółdzielnia socjalna są bardzo zróżnicowane. Tym samym przedmiotem artykułu będzie omówienie modyfikacji zachodzących w regulacjach prawnych oraz ich skuteczności dla rozwoju spółdzielni socjalnych w Polsce. 


\section{Fundusz zasobowy jako narzędzie budowania stabilizacji ekonomicznej spółdzielni}

Gospodarka finansowa spółdzielni oparta jest o środki zgromadzone na właściwych funduszach. Jednym z nich jest fundusz zasobowy. Spółdzielnia zobowiązana jest podnosić jego wartość o wyznaczoną część nadwyżki bilansowej, która wynosi zgodnie z ogólnymi wytycznymi prawa spółdzielczego, co najmniej 5\% nadwyżki bilansowej ${ }^{9}$. Taka kwota może być wystarczająca w przypadku typowej spółdzielni, jednak spółdzielnia socjalna w tym zakresie odbiega od wytycznych ogólnych. Ze względu na nałożone przez ustawodawcę obowiązki w zakresie reintegracji społecznej i zawodowej osób wykluczonych oraz prowadzenie działalności gospodarczej, zdecydował on o przeznaczeniu w początkowym okresie istnienia spółdzielni socjalnej 40\% nadwyżki bilansowej na opisywany fundusz. Takie rozwiązanie było skuteczne, ponieważ budowało stabilizację organizacji w przypadku, gdy podejmowała ona działania na lokalnym rynku. $Z$ czasem okazało się jednak istotnym ograniczeniem. Przede wszystkim wynikało to $\mathrm{z}$ faktu, iż fundusz zasobowy nie może być przeznaczany na bieżący rozwój spółdzielni. Służy on, bowiem do pokrycia strat powstałych $\mathrm{w}$ wyniku działalności organizacji ${ }^{10}$. Dla rozwoju spółdzielni niezbędne były większe środki przeznaczane na cele gospodarcze, związane z budowaniem przewagi konkurencyjnej. Takie rozłożenie nadwyżki bilansowej w spółdzielni socjalnej prowadziło do zamrożenia wskazanych środków.

Stosowne zmiany dokonane w 2017 r. wpłynęły na tę sytuację. Obniżenie maksymalnego progu z nadwyżki bilansowej na fundusz zasobowy obejmującego nie mniej niż $20 \%$ pozwoliło spółdzielniom na to, iż stały się bardziej konkurencyjne ${ }^{11}$. Takie rozwiązanie pozwala rozdysponować środki na fundusze przeznaczone na cele gospodarcze lub społeczne według decyzji podejmowanych przez władze spółdzielni. Na uwagę zasługuje również fakt, iż spółdzielnie socjalne coraz częściej dysponują znacznymi środkami finansowymi - nadwyżka stanowi zatem istotne zabezpieczenie ewentualnych strat.

9 Zob. art. 76 ustawy z dnia 16 września 1982 r. Prawo spółdzielcze, tekst jednolity:

Dz. U. z 2018 r. poz. 1285 z późn. zm. (dalej: u.p.s.).

10 Zob. art. 78 u.p.s.

11 Zob. art. 1 pkt 8 u.s.s.2017. 
Innym aspektem wpływającym na wielkość funduszu zasobowego jest wysokość wkładu wpłacanego przez członków spółdzielni socjalnej. Tym samym im większa liczba członków takiej organizacji - tym większa wartość środków budująca fundusz zasobowy. Członkami spółdzielni socjalnej mogą być nie tylko osoby fizyczne, ale także osoby prawne, które przeznaczają swoje środki na budowanie funduszu zasobowego. Takie rozwiązanie jest korzystne zwłaszcza dla nowych organizacji wchodzących na rynek. Podobnie jak w przypadku innych podmiotów gospodarki spółdzielczej, do których niewątpliwie można zaliczyć banki spółdzielcze, ich wielkość nie przesądza o ich konkurencyjności. Spółdzielnie socjalne, podobnie jak banki spółdzielcze, dostosowują się do zmieniających się warunków podnosząc wielkość funduszu zasobowego w zależności od sytuacji gospodarczej na lokalnym rynku. Mogą one podwyższać wysokość takiego funduszu decyzją Walnego Zgromadzenia przy zachowaniu minimalnej wartości $20 \%$ nadwyżki bilansowej ${ }^{12}$. $Z$ racji na to, iż spółdzielczość socjalna najlepiej realizuje swoje cele przy niewielkich strukturach często dochodzi do podziału takich podmiotów i wyłonienia $\mathrm{z}$ nich nowych jednostek. Ma to miejsce nie tylko w przypadku spółdzielni socjalnych tworzonych przez osoby fizyczne, ale także osoby prawne.

Środki na wkład własny mogą pochodzić z kilku źródeł. W przypadku osób z niepełnosprawnością najczęściej jest to Państwowy Fundusz Rehabilitacji Osób Niepełnosprawnych (PFRON), który przekazuje dotacje na wkład członkowski do spółdzielni socjalnej. W przypadku niedotrzymania warunków umowy podlegają one zwrotowi, na warunkach szczególnych, kiedy to umorzenie może nastąpić jedynie w skrajnych przypad$\mathrm{kach}^{13}$. Z kolei osoby bezrobotne i korzystające $\mathrm{z}$ zatrudnienia socjalnego mogą skorzystać z Funduszu Pacy przeznaczając pozyskane środki na część wkładu na fundusz zasobowy. Warunkiem ich uzyskania jest posiadanie statusu osoby bezrobotnej, bowiem jest to podstawowy czynnik decydujący o uzyskaniu wsparcia i odwrotnie - przystąpienie do spółdzielni

12 Zob. E. Gostomski, B. Lepczyński, Znaczenie członkostwa w kształtowaniu bezpieczeństwa finansowego i funduszy własnych w polskich bankach spótdzielczych, "Zeszyty Naukowe - Uniwersytet Szczeciński. Finanse, Rynki Finansowe, Ubezpieczenia” 2018, nr 1 (91): Zarządzanie finansami, s. 407.

13 Zob. orzeczenie Wojewódzkiego Sądu Administracyjnego we Wrocławiu z dnia 18 października 2017 r., III SA/Wr 495/17, Centralna Baza Orzeczeń Sądów Administracyjnych (CBOSA). 
socjalnej nie pozwala na uzyskanie statusu bezrobotnego ${ }^{14}$, chyba że funkcja w zarządzie jest wykonywana $\mathrm{w}$ formie wolontariatu, co nie blokuje gotowości do podjęcia pracy zarobkowej ${ }^{15}$. Wycofanie się danej osoby ze spółdzielni socjalnej wiąże się natomiast z koniecznością zwrotu przyznanej dotacji. Umorzenie jej wartości następuje w skrajnym przypadku, gdyż zwrócone środki mogą być wykorzystane na dofinansowanie innych projektów wspieranych z Funduszu Pracy ${ }^{16}$ oraz PFRON ${ }^{17}$. W ostatnim czasie realizowanych jest wiele projektów unijnych, których celem jest powstanie nowych spółdzielni socjalnych. Obejmują one nie tylko szkolenie osób wykluczonych, co pozwala na budowanie w nich zdolności interpersonalnych, ale także przekazywanie wiedzy na temat ekonomii społecznej. Końcowym etapem danego projektu może być uzyskanie środków z funduszy unijnych na pokrycie wkładu na fundusz zasobowy w tworzącej się spółdzielni socjalnej. Ich zwrot $\mathrm{w}$ przypadku nie rozpoczęcia działalności lub przerwania jej przed wyznaczonym terminem również prowadzi do obniżenia wartości funduszu, a w konsekwencji spadku wiarygodności spółdzielni w stosunku do zewnętrznych przedsiębiorców ${ }^{18}$.

Problemem przy określeniu wielkości funduszu zasobowego jest właściwe prowadzenie gospodarki finansowej spółdzielni. Wiele podmiotów spółdzielczych posiadało prawo do uproszczonej księgowości na mocy właściwych przepisów ${ }^{19}$ (uchylone w 2014 r. $^{20}$ ), co należy uznać za krok

14 Zob. orzeczenie Wojewódzkiego Sądu Administracyjnego w Warszawie z dnia 8 lutego 2017 r., II SA/Wa 1246/16, CBOSA.

15 Zob. orzeczenie Naczelnego Sądu Administracyjnego z dnia 17 lutego 2017 r., I OSK 2732/15, CBOSA; orzeczenie Wojewódzkiego Sądu Administracyjnego z dnia 27 października 2015 r., II SA/Wa 432/15, CBOSA.

16 Zob. orzeczenie Wojewódzkiego Sądu Administracyjnego w Poznaniu z dnia 3 sierpnia 2017 r., II SA/Po 294/17, CBOSA.

17 Zob. orzeczenie Wojewódzkiego Sądu Administracyjnego we Wrocławiu z dnia 18 października 2017 r., III SA/Wr 495/17, CBOSA.

18 Zob. orzeczenie Wojewódzkiego Sądu Administracyjnego w Warszawie z dnia 7 lutego 2018 r., V SA/Wa 675/17, CBOSA; orzeczenie Wojewódzkiego Sądu Administracyjnego w Warszawie z dnia 17 września 2015 r., V SA/Wa 835/15, CBOSA.

19 Wówczas, zgodnie z art. 2 ust. 1 pkt 2 ustawy z dnia 29 września 1994 r. o rachunkowości (tekst jednolity: Dz. U. z 2013 r., poz. 330), spółdzielnie socjalne, których przychody netto ze sprzedaży towarów, produktów i operacji finansowych za poprzedni rok obrotowy wyniosły co najmniej równowartość w walucie polskiej 1200000 euro mogły korzystać z uproszczonej księgowości. Niestety przepis ten pozostawał martwy ponieważ nie sprecyzowano formy w jakiej spółdzielnie socjalne mogły taki przywilej realizować. 
w dobrym kierunku. Takie rozwiązanie pozwala spółdzielniom socjalnym unikać wielu błędów proceduralnych, a to ma istotny wpływ na realizowanie przez nie celów ekonomicznych i społecznych. Zgodnie ze zmianami wprowadzonymi w 2014 r. wszystkie podmioty w tym spółdzielnie socjalne spełniające kryteria przedsiębiorców mikro mogą korzystać ze zdefiniowanych uprawnień. Za przedsiębiorcę mikro uznaje się podmiot, który w roku obrotowym, za który sporządzają sprawozdanie finansowe oraz w roku poprzedzającym ten rok obrotowy, nie przekroczyły, co najmniej dwóch z następujących trzech wielkości, czyli: 1500000 zł - w przypadku sumy aktywów bilansu na koniec roku obrotowego oraz 3000000 zł - w przypadku przychodów netto ze sprzedaży towarów i produktów za rok obrotowy oraz 10 osób - w przypadku średniorocznego zatrudnienia w przeliczeniu na pełne etaty ${ }^{21}$. W przypadku spółdzielni socjalnych niezbędna jest zgoda Walnego Zgromadzenia na sporządzenie sprawozdania finansowego w sposób właściwy dla przedsiębiorców mikro. Pozwala to spółdzielniom socjalnym przedstawiać rachunek zysków i strat oraz informację dodatkową w sposób uproszczony. Władze nie są zobowiązane do przekazywania informacji o zatrudnieniu $\mathrm{z}$ lat przeszłych oraz wiedzy o znaczących zdarzeniach mających wpływ na rozwój podmiotu. Takie rozwiązanie nie jest obligatoryjne dla spółdzielni ${ }^{22}$. Pozostałe spółdzielnie socjalne nie spełniające tych kryteriów zobowiązane są rozliczać się stosując pełną księgowość. Pozwala to na szerszą identyfikację przepływów finansowych wewnątrz organizacji oraz identyfikowanie szans na dalszy rozwój. Ograniczeniem tej metody są oczywiście koszty, które stanowią istotne ograniczenie - zwłaszcza dla nowych podmiotów wchodzących na rynek ${ }^{23}$.

Fundusz zasobowy w sprawozdaniu spółdzielni socjalnej został zdefiniowany w kapitale zapasowym. Tym samym władze spółdzielni mogą zidentyfikować ile środków ma podmiot do dyspozycji na pokrycie strat oddzielając je od funduszu fakultatywnego, wzajemnościowego i innych

20 Art. 1 pkt 1 ustawy z dnia 11 lipca 2014 r. o zmianie ustawy o rachunkowości, Dz. U. z 2014 r. poz. 1100 (dalej: u.r.2014).

${ }^{21}$ Art. 1 pkt 2 u.r.2014.

22 Zob. W. Żbik (red.), Jak przygotować spótdzielnię socjalna do lustracji, seria: Biblioteka Spółdzielczości Socjalnej, t. 9, Warszawa 2015, s. 89.

${ }_{23}$ Zob. J. Zych, Księgi rachunkowe a zarządzanie spótdzielnia mieszkaniowa, [w:] P. Lenik (red.), Zarzadzanie w sektorach prywatnym oraz publicznym, seria: Prace Naukowo-Dydaktyczne Państwowej Wyższej Szkoły Zawodowej im. Stanisława Pigonia w Krośnie, z. 70, Krosno 2016, s. 413. 
funduszy fakultatywnych. W przeciwieństwie do przedsiębiorstw komercyjnych, w przypadku spółdzielni zysk netto definiowany jest jako nadwyżka bilansowa, czyli środki pozostające do dyspozycji władz spółdzielni po odliczeniu zobowiązań podatkowych i innych. Przeciwieństwem nadwyżki bilansowej jest pojęcie straty bilansowej pokrywanej bezpośrednio z funduszu zasobowego, a w przypadku jego niedostatku, z bieżących środków spółdzielni. Zauważyć należy, iż w pewnych okolicznościach fundusz zasobowy spółdzielni socjalnej może być również wydatkowany na środki trwałe, materiały i urządzenia niezbędne do rozpoczęcia działalności podmiotu. Prowadzi to do przyznania im statusu kosztów uzyskania przychodu pod warunkiem, iż zostaną one we właściwy sposób zdefiniowane poprzez zastosowanie art. 15 i 16 ustawy o podatku dochodowym od osób prawnych ${ }^{24}$. W przypadku, gdy po pokryciu wszystkich zobowiązań pozostaną dodatkowe środki podlegają one podziałowi pomiędzy członków spółdzielni socjalnej, chyba że pochodzą one ze środków publicznych wówczas są zwracane do Funduszu Pracy, gdzie służą budowaniu kolejnych miejsc pracy w spółdzielniach socjalnych ${ }^{25}$.

\section{Fundusze fakultatywne metodą finansowania zadań społecznych spółdzielni socjalnej}

Spółdzielnia socjalna od początku swojego istnienia jest zobligowana do realizacji dwóch celów o charakterze społecznym. Jednym z nich jest działalność związana z reintegracją społeczną - obejmująca budowanie i podtrzymanie relacji w lokalnej społeczności pozwalających im odnaleźć się i właściwie w niej funkcjonować. Uzupełnieniem tych działań jest reintegracja zawodowa - polegająca na odbudowaniu i utrzymaniu zdolności do samodzielnej pracy na rynku².

24 Zob. Interpretacja indywidualna Dyrektora Izby Skarbowej w Warszawie z dnia 30 października 2014 r., IPPB5/423-971/14-2/AM, http://sip.mf.gov.pl/faces/views/ szczegoly/szczegoly-interpretacji indywidualnej.xhtml?dokumentId=411936\&poziomDo stepu=PUB\&indexAccordionPanel=-1\#tresc [dostęp: 1.08.2018 r.].

${ }_{25}$ Zob. D. Krzywda, Fundusze własne spótdzielni mieszkaniowych jako przedmiot sprawozdawczości i rewizji finansowej, [w:] B. Micherda (red.), Sprawozdawczość i rewizja finansowa: uwarunkowania ekonomiczne, społeczne i regulacyjne, Kraków 2015, s. 207.

26 Zob. art. 2 ust. 2 u.s.s. 2006. 
Działania takie powinny być realizowane w stosunku do członków spółdzielni w ramach prowadzonej przez podmiot działalności gospodarczej. Zmiany w sektorze spółdzielczości wymusiły istotne zmiany w tym zakresie. Przyczyną takich działań było pojawienie się na rynku spółdzielni socjalnych osób prawnych, które zatrudniały pracowników, zaś członkostwo w spółdzielni uzyskiwali oni po okresie próbnym ${ }^{27}$. Spowodowało to, iż wiele spółdzielni nie podejmowało wobec tej grupy żadnych działań w zakresie realizacji celów społecznych. Sytuacja była inna w przypadku spółdzielni socjalnych założonych przez osoby fizyczne, gdyż tutaj oddziaływania reintegracyjne wymuszał fakt przyjęcia nowych osób w poczet członków, zaś pracownikami spółdzielni najczęściej pozostawały osoby, które wspierały spółdzielnię w jej rozwoju pełniąc rolę doradczą. Takie odmienne traktowanie członków i pracowników spółdzielni socjalnej doprowadziło do włączenia pracowników w zakres oddziaływań związanych z integracją społeczną i zawodową ${ }^{28}$.

Wsparcie w zakresie reintegracji objęło jedynie grupę pracowników, która charakteryzowała się ich wykluczeniem. Wskazać należy, iż do tej grupy zaliczane są osoby z niepełnosprawnością, bezrobotne, korzystające z zatrudnienia socjalnego, osoby w wieku do lat 30 i po 50. roku życia posiadające status osób poszukujących pracy czy osoby usamodzielniające się. To rozwiązanie należy ocenić pozytywnie zwłaszcza, że w tym przypadku proces ten realizowany jest $\mathrm{w}$ trakcie wykonywania obowiązków na rzecz spółdzielni.

W ramach działania spółdzielni socjalnej środki z nadwyżki bilansowej przeznaczone na fundusz fakultatywny związany z reintegracją społeczną są kierowane na działania proobywatelskie obejmujące spotkania z lokalnymi decydentami, które mają zmienić ich podejście do spółdzielni socjalnych i ich działalności. Można to zdefiniować jako działalność lobbingową i rzeczniczą na rzecz szeroko rozumianego ruchu spółdzielczego. Poza tym, spółdzielnia może przeznaczyć środki z tego funduszu na działalność samopomocową dla członków i pracowników z zakresu spraw pozapracowniczych. Wyróżnić tutaj można pomoc w zakupie opału, prace porządkowe w miejscach zamieszkania czy załatwianie bieżących spraw, jak zrobienie zakupu czy zapewnienie opieki nad dzieckiem. Ma to istot-

27 Zob. M. Sobczak, Reintegracja społeczno-zawodowa osób po 45 roku życia w spótdzielniach socjalnych, „Acta Universitatis Lodziensis” 2015, t. 312, nr 2, s. 176.

28 Zob. art. 1 pkt 1 u.s.s. 2017. 
ne znaczenie zwłaszcza w przypadku osób wykluczonych, które bez takiej pomocy nie mogą podjąć pracy, a tym samym zapewnić bytu swoim najbliższym. Reintegracja społeczna może obejmować również środowisko pracy. Należy tutaj wymienić współdziałanie w wykonywaniu zadań oraz wszelką działalność o charakterze integracyjnym, jak chociażby wspólne szkolenia czy wyjazdy ${ }^{29}$.

Środki z funduszu fakultatywnego mogą być również przeznaczone na reintegrację zawodową. Można z niego finansować wsparcie specjalistów dla członków i pracowników spółdzielni, do których należy zaliczyć doradcę zawodowego lub psychologa pracy ${ }^{30}$. Spółdzielnia nie musi zatrudniać takich pracowników na stałe. Może zlecać im wykonanie konkretnych zadań na podstawie odrębnej umowy, jeśli osoby te prowadzą działalność gospodarczą. W przypadku, gdy spółdzielnia zdecyduje się, aby taka osoba posiadała status członka może ona wykonywać takie zadania w oparciu o umowę cywilnoprawną, co ogranicza koszty jej zatrudnienia. Takie rozwiązanie musi być jednak dookreślone w statucie spółdzielni socjalnej ${ }^{31}$.

Środki funduszu fakultatywnego przeznaczonego na realizację celów związanych z reintegracją społeczną i zawodową pochodzą przede wszystkim z nadwyżki bilansowej. Spółdzielnia socjalna może założyć również w statucie przekazanie części środków z wkładu nowych członków. Ma to istotne znaczenie zwłaszcza w przypadku nowych spółdzielni, które poza rozpoczęciem działalności gospodarczej muszą realizować cele związane z reintegracją społeczną i zawodową swoich członków ${ }^{32}$.

Oceniając sytuację finansową spółdzielni socjalnej, organy administracji publicznej oraz inne organizacje pozarządowe podejmujące współpracę $\mathrm{z}$ takim podmiotem powinny brać pod uwagę nie tylko fundusz zasobowy, ale także i wielkość funduszu celowego. W przeciwieństwie do innych typów spółdzielni, wyłonienie takiego funduszu w spółdzielni socjalnej ma charakter obligatoryjny i pozwala na realizację wielu celów pozaekonomicznych, odciążając tym samym inne - przeznaczone na kon-

29 Zob. M. Pleśniak, Reintegracyjna funkcja spótdzielni socjalnych, [w:] J. Blicharz, L. Zacharko (red.), Trzeci sektor i ekonomia społeczna. Uwarunkowania prawne. Kierunki działań, Wrocław 2017, s. 227.

30 Zob. K. Moskaluk-Łągiewczyk, Status prawny spótdzielni socjalnych, „Folia Iuridica Wratislaviensis" 2012, t. 1, nr 1, s. 162.

31 Zob. art. 201 u.p.s.

32 Zob. J. Zych, Księgi rachunkowe a zarzadzanie..., s. 416. 
kretne inwestycje gospodarcze. Dzięki utrzymywaniu funduszu celowego opisane wyżej podmioty, przy realizacji projektów społecznych, mogą ocenić wiarygodność partnerów, którymi mogą być jednostki samorządu terytorialnego oraz stowarzyszenia czy fundacje tworzące lokalne partnerstwa działające w ramach usług działalności pożytku publicznego ${ }^{33}$.

Ustalenie wysokości funduszu celowego w spółdzielni socjalnej uzależnione jest bezpośrednio od zapisów zawartych w samej ustawie. Początkowo wynosiła ona, co najmniej 40\% uzyskanej przez spółdzielnię nadwyżki bilansowej ${ }^{34}$. Było to spowodowane koniecznością zabezpieczenia środków na realizację celów związanych z reintegracją społeczną i zawodową. Dokonując analizy sytuacji finansowej wybranych spółdzielni socjalnych zauważono, iż minimalna granica wydatkowanych na ten cel środków powinna zostać obniżona ze względu na konieczność pozostawienia większej swobody władzom spółdzielni. To one, nie ustawodawca, powinny decydować zgodnie z podstawami prawa spółdzielczego o rozdysponowaniu środków na poszczególne cele ${ }^{35}$. Taki pogląd leżał u podstaw zmian $w$ przepisach prawa, które obniżyły próg przeznaczanej nadwyżki bilansowej na fundusz fakultatywny do co najmniej $30 \%{ }^{36}$. Rozwiązanie to pozwala na to, że decyzją Walnego Zgromadzenia mogą oni wprowadzić w statucie możliwość podwyższenia wielkości takiego funduszu dookreślając również stosowne kryteria takiej decyzji. Powinno być to zależne od wielkości spółdzielni, kategorii członków, w tym zdefiniowania ich problemów, środowiska lokalnego, w których funkcjonuje spółdzielnia oraz zasobów, jakimi dysponują lokalne władze czy organizacje pozarządowe. Takie działania w istotny sposób winny stanowić uzupełnienie usług świadczonych przez tego typu podmioty jako ogólnodostępne ${ }^{37}$. Należy dodatkowo pamiętać, iż owe kryteria muszą być wprowadzone dopiero po dyskusji wewnątrz organizacji nie zaś bezpośrednio narzucane z zewnątrz.

${ }^{33}$ Zob. J. Zuba, M. Zuba-Ciszewska, Wptyw kapitału wtasnego na rentowność i bezpieczeństwo finansowe wybranych spótdzielni mleczarskich w Polsce, „Roczniki Naukowe Stowarzyszenia Ekonomistów Rolnictwa i Agrobiznesu" 2014, z. 2, s. 310.

34 Zob. art. 10 ust. 1 pkt 2 u.s.s.2006.

35 Zob. R. Ostrowski, Podział nadwyżki bilansowej w spótdzielni, „Mieszkanie i Wspólnota" 2012, nr 5, s. 15.

36 Zob. art. 1 pkt 7 u.s.s. 2017.

37 J. Sklarz, Model finansowania spótdzielni mieszkaniowych a ewidencja kosztów, „Studia Ekonomiczne" 2005, nr 33, s. 306. 
Nadwyżka bilansowa spółdzielni socjalnej przeznaczona na fundusz fakultatywny i zasobowy jest traktowana jako dochód spółdzielni. Tym samym podlega on opodatkowaniu na takich samych zasadach, jak dochód innych przedsiębiorców. Zgodnie z przyjętą interpretacją organów podatkowych może on być zwolniony z podatku dochodowego od osób prawnych. Aby spełnić ten warunek nadwyżka bilansowa uzyskana $\mathrm{w}$ danym roku musi być $\mathrm{w}$ nim wydatkowana oraz przeznaczona na cele statutowe organizacji związane $\mathrm{z}$ reintegracją społeczną i zawodową, po wcześniejszym sklasyfikowaniu, czy nie stanowi kosztów uzyskania przychodu. Odrzucenie tej klasyfikacji jako koszty uzyskania przychodu pozwala na zastosowanie zwolnienia ${ }^{38}$. Wskazać jednak należy, iż zwolnienie może dotyczyć jedynie części nadwyżki przeznaczonej na fundusz fakultatywny związany z realizacją celów społecznych, nie zaś kierowanej do funduszu zasobowego ${ }^{39}$, który nie jest przychodem w przypadku rozpoczęcia działalności gospodarczej i pozyskania środków na ten cel ze środków zewnętrznych jak chociażby funduszy unijnych ${ }^{40}$. Zauważyć należy, iż w przypadku zmiany przeznaczenia dochodów na inny cel niż fundusz fakultatywny podmiot zobowiązany jest do zapłaty właściwego podatku bez wezwania organu. Takie rozwiązanie wymaga szczególnej uwagi ze strony władz spółdzielni socjalnej, ponieważ może prowadzić do zakłóceń stabilizacji finansowej podmiotu ${ }^{41}$.

Spółdzielnia socjalna realizując swoje działania może korzystać także ze wsparcia osób trzecich. Niewątpliwie zaliczyć można do nich użyczenie samochodów do celów gospodarczych. O ile takie rozwiązanie generuje dochód, a nie prowadzi do powstania kosztów, są one objęte skalą podat-

38 Zob. art. 17 ust. 1 pkt 43 ustawy z dnia 15 lutego 1992 r. o podatku dochodowym od osób prawnych, tekst jednolity: Dz. U. z 2019 r. poz. 865.

39 Zob. Interpretacja indywidualna Dyrektora Izby Skarbowej w Bydgoszczy z dnia 17 czerwca 2015 r., ITPB3/4510-157/15-4/PS, http://sip.mf.gov.pl/faces/views/szczegoly/szczegoly-interpretacji indywidualnej.xhtml?dokumentId=451912\&poziomDostepu =PUB\&indexAccordionPanel=-1\#tresc [dostęp: 1.08.2018 r.].

40 Zob. Interpretacja indywidualna Dyrektora Krajowej Informacji Skarbowej z dnia 13 października 2018 r., 0112-KDIL3-3.4010.22.2017.2.MC, http://sip.mf.gov.pl/faces/ views/szczegoly/szczegoly-interpretacji indywidualnej.xhtml?dokumentId=517577\&poz iomDostepu= PUB\&indexAccordionPanel=-1\#tresc [dostęp: 1.08.2018 r.].

${ }^{41}$ Zob. Interpretacja indywidualna Dyrektora Izby Skarbowej w Warszawie z dnia 9 grudnia 2015 r., IPPB5/4510-985/15-3/AK, http://sip.mf.gov.pl/faces/views/szczegoly / szczegoly-interpretacji-indywidualnej.xhtml?dokumentId=456474\&poziomDostepu =PUB\&indexAccordionPanel=-1\#tresc [dostęp: 1.08.2018 r.]. 
kową pod warunkiem, iż nie są przekazywane na cele społeczne. $W$ takim przypadku podlegają zwolnieniu po spełnieniu omówionych wyżej wytycznych dotyczących czasu wydatkowania i kwalifikacji kosztów ${ }^{42}$.

Ustawodawca zakładając zastosowanie zwolnienia środków przeznaczonych na fundusz związany z rehabilitacją społeczną i zawodową wskazał również na to, iż wszystkie środki przeznaczone na ten cel muszą pochodzić z działalności gospodarczej i muszą być w ramach tej działalności realizowane. $W$ przypadku, gdy spółdzielnia będzie realizować swoje cele związane z reintegracją społeczną i zawodową poza działalnością gospodarczą spółdzielni będą podlegać obowiązkowi płacenia podatków bez możliwości zastosowania przedmiotowego zwolnienia ${ }^{43}$.

\section{Inwestycje spółdzielni sposobem na podnoszenie konkurencyjności ekonomicznej podmiotu}

Spółdzielnie socjalne zobligowane były do przeznaczania znacznej części swojej nadwyżki bilansowej na fundusz inwestycyjny. Ustawodawca nie zdefiniował minimalnej granicy środków przeznaczanych na ten cel, gdyż miało to leżeć w gestii władz spółdzielni. Jednak zgodnie z zapisami ustawy, na fundusz udziałowy należało przeznaczyć, co najmniej $40 \%$ nadwyżki, podobnie jak $\mathrm{w}$ przypadku funduszu celowego. Tym samym do dyspozycji funduszu inwestycyjnego pozostało jedynie $20 \%$ nadwyżki bilansowej ${ }^{44}$. Mógł być on przeznaczony bezpośrednio na realizację konkretnych inwestycji podnoszących konkurencyjność spółdzielni, nie tylko w aspekcie prowadzonej działalności, ale także jej rozszerzenia. Tym samym władze spółdzielni socjalnej miały prawo rozdysponować te środki na zakup nowych urządzeń czy materiałów niezbędnych do aktualnej pro-

${ }^{42}$ Zob. Interpretacja indywidualna Dyrektora Izby Skarbowej w Katowicach z dnia 30 grudnia 2012 r., IBPBI/2/423-1220/14/MO, http://sip.mf.gov.pl/faces/views/szczegoly/szczegoly-interpretacji nwidualej.xhtm 1?dokumentId=412751\&poziomDostepu=PU B\&indexAccordionPanel=-1\#tresc [dostęp: 1.08.2018 r.].

43 Zob. Indywidualna interpretacja Dyrektora Izby Skarbowej w Bydgoszczy z dnia 11 lipca 2017 r., ITPB3/4510-189/16/DK, http://sip.mf.gov.pl/faces/views/szczegoly/ szczegoly-interpretacji-indywidualnej.xhtml? dokumentId=484942\&poziomDostepu=PU B\&indexAccordionPanel=-1\#tresc [dostęp: 1.08.2018 r.].

${ }_{44}$ Zob. art. 10 ust. 1 pkt 3 u.s.s. 2006. 
dukcji czy świadczenia usług, lecz także na rozwijanie spółdzielni poprzez rozszerzenie zakresu jej działalności. Takie rozwiązanie pozwoliłoby na zwiększenie liczby miejsc pracy dla osób wykluczonych, co ma istotne znaczenie dla ograniczenia tego zjawiska zwłaszcza na obszarach wiejskich ${ }^{45}$.

Ustalenie wielkości funduszu inwestycyjnego było uzależnione od władz spółdzielni. Walne Zgromadzenie mogło określić w statucie spółdzielni wysokość nadwyżki bilansowej kierowanej na ten cel. Zależało to najczęściej od środowiska lokalnego, w którym rozwijał się podmiot. Organa spółdzielni brały pod uwagę wielkość bezrobocia, zagrożenie wykluczeniem społecznym wśród członków, potencjał gospodarczy organizacji oraz wielkość środków przeznaczanych na pozostałe fundusze. Miało to istotne znaczenie zwłaszcza w przypadku zakresu działań podejmowanych przez podmiot związanych z reintegracją społeczną. Gdy ich liczba była znacząca, a spółdzielnia nie mogła liczyć na wsparcie zewnętrzne, wówczas dochodziło do jego podwyższenia nawet powyżej minimalnej kwoty wskazanej w ustawie. W konsekwencji na fundusz inwestycyjny przeznaczanych było mniej środków, co zmniejszało konkurencyjność jednostki spółdzielczej. Szansą na zmianę sytuacji było zawiązanie partnerstw z organizacjami pozarządowymi i administracją publiczną, które pomogłyby odciążyć fundusz fakultatywny przeznaczony na cele związane $\mathrm{z}$ reintegracją społeczną i zawodową, a zaoszczędzone środki przeznaczyć na fundusz inwestycyjny ${ }^{46}$.

W przypadku dużych miast powstające na tym terenie spółdzielnie socjalne miały zdecydowanie większe szanse na powiększanie funduszu inwestycyjnego. Wynikało to przede wszystkim z faktu, iż w takich rejonach bardziej dostępna pozostaje zewnętrzna pomoc realizująca zadania w zakresie reintegracji społecznej i zawodowej. Świadczą ją w takim przypadku już nie tylko spółdzielnie socjalne, ale także organizacje pozarządowe korzystające $z$ funduszy unijnych czy krajowych. Powstające $w$ ten sposób parterstwa były zdecydowanie silniejsze zastępując w tej kwestii spółdzielnie. Duży rynek zbytu umożliwiał spółdzielni, rozwijanie także

45 Zob. M. Zuba-Ciszewska, Wptyw koncentracji kapitatu własnego na jego efektywność w wybranych spótdzielniach mleczarskich w Polsce w latach 2003-2012, "Zeszyty Naukowe Szkoły Głównej Gospodarstwa Wiejskiego w Warszawie. Ekonomika i Organizacja Gospodarki Żywnościowej" 2015, nr 109, s. 107.

46 Zob. M. Błażejowska, Funkcjonowanie podmiotów ekonomii społecznej na obszarach wiejskich na przykładzie spótdzielni socjalnych, "Zeszyty Naukowe Szkoły Głównej Gospodarstwa Wiejskiego w Warszawie - Problemy Rolnictwa Światowego" 2011, t. 11 (26), z. 4, s. 27. 
jej potencjału gospodarczego. Fundusz inwestycyjny był zdecydowanie wyższy i lepiej zagospodarowany niż w przypadku mniejszych podmiotów działających poza centrami wielkich miast ${ }^{47}$.

W najnowszych przepisach wprowadzono stosowne zmiany eliminujące fundusz inwestycyjny z obowiązkowych funduszy spółdzielni socjalnej ${ }^{48}$. Tym samym zarówno spółdzielnie socjalne tworzone przez osoby fizyczne, jak i prawne, mają szerszą możliwość kształtowania kierunków rozwoju organizacji. W pierwszym przypadku dla rozwoju spółdzielni powoływane są fundusze, które zostają wyłonione w wyniku decyzji Walnego Zgromadzenia. Podczas jego obrad zarówno członkowie Zarządu, jak i szeregowi członkowie mogą wypowiedzieć się na temat tego, które z działań uznawane jest za najbardziej istotne i na które należy przeznaczyć zadysponowane z nadwyżki bilansowej środki. Zmniejszenie minimalnego obowiązkowego udziału pozostałych funduszy pozwala na swobodne przeznaczanie dochodu na rozwój konkurencyjności organizacji. Jest to zdecydowanie łatwiejsze w przypadku spółdzielni socjalnych osób fizycznych, gdzie członkowie są bardziej świadomi kierunków rozwoju swojej organizacji niż w przypadku spółdzielni socjalnej osób prawnych, gdzie jedynie część osób posiada wiedzę na temat zarządzania spółdzielnią socjalną. Są one najczęściej przedstawicielami osób prawnych tworzących spółdzielnię nie zaś jej członków będących osobami wykluczonymi. Tym samym wybór kierunków działania w zakresie gospodarowania spółdzielnią celem podnoszenia jej konkurencyjności jest bardziej skuteczny w spółdzielniach socjalnych osób fizycznych ${ }^{49}$.

Likwidacja funduszu inwestycyjnego na rzecz tworzenia funduszy dobrowolnych przeznaczonych na rozwijanie działalności przez spółdzielnię socjalną przyniosło dodatkową korzyść. Jest nią prostota wydatkowania środków oraz ich monitorowania podczas procedury lustracji. Pozwala to na ocenę przeznaczenia funduszy na konkretny cel pod względem gospodarności i celowości ${ }^{50}$. W przypadku nowych spółdzielni ma

47 Zob. M. Czarkowski, Spótdzielnie socjalne w Warszawie, „Ekonomia Społeczna” 2013, nr 3, s. 138.

48 Zob. art. 1 pkt 8 u.s.s.2017.

49 Zob. M.J. Sobczak, Dwa światy spółdzielni socjalnych w Polsce, „Ekonomia Społeczna” 2016, nr 2, s. 9.

50 Zob. J. Dworniak, M. Pietrzak, Spółdzielczość mleczarska - specyfika ekonomiczna i rola rewizji finansowej w nadzorze korporacyjnym, "Studia Prawno-Ekonomiczne” 2014, t. 91, cz. 2, s. 64 . 
to o tyle istotne znaczenie, iż pozwala Zarządowi i członkom spółdzielni właściwie realizować zadania w oparciu o wiarygodne dane skierowane na konkretny projekt gospodarczy realizowany przez podmiot.

Z punktu widzenia prawa podatkowego nadmienić należy, iż środki przeznaczane na fundusze o charakterze gospodarczym podlegają obowiązkowi podatkowemu. Dotyczy to również sytuacji, gdy środki pochodzą z funduszy pomostowych finansowanych ze środków unijnych na działalność gospodarczą. W określonych przez ustawodawcę przypadkach mogą być one kwalifikowane jako koszty uzyskania przychodu, ale jedynie $\mathrm{w}$ zakresie przeznaczenia ich na działalność gospodarczą ${ }^{51}$; $\mathrm{w}$ pozostałych zaś przypadkach stanowią dochód podlegający opodatkowaniu ${ }^{52}$.

W przypadku, gdy spółdzielnia nie prowadzi działalności, fundusze na projekty gospodarcze nie są gromadzone mimo zgody Walnego Zgromadzenia. Wówczas podmiot podlega takim samym sankcjom jak inni przedsiębiorcy, gdy wystawia dokumenty potwierdzające określone zdarzenie gospodarcze nawet w sytuacji, gdy realizuje zadania z zakresu reintegracji społecznej i zawodowej swoich członków oraz zatrudnionych tam pracowników ${ }^{53}$.

\section{Konsorcjum spółdzielcze a sposoby jego finansowania w ramach funduszu wzajemnościowego}

Spółdzielnie socjalne organizując się tworzą partnerstwa dla realizacji celów społecznych i ekonomicznych. Dotychczas nie były one jednak prawnie uregulowane. Powołanie do życia konsorcjum spółdzielczego

51 Zob. Interpretacja indywidualna Dyrektora Izby Skarbowej w Katowicach z dnia 3 lutego 2017 r., 2461-IBPB-1-2.4510.1005.2016.2.MS, http://sip.mf.gov.pl/faces/views/ szczegoly/szczegoly-interpretacji-indywidualnej.xhtml?dokumentId=497868\&poziomDo stepu=PUB\&indexAccordionPanel=-1\#tresc [dostęp: 1.08.2018 r.].

52 Zob. Indywidualna interpretacja Dyrektora Izby Skarbowej w Katowicach z dnia 3 lutego 2017 r., 2461-IBPB-1-2.4510.1142.2016.1.MS, http://sip.mf.gov.pl/faces/views/ szczegoly / szczegoly-interpretacji-indywidualnej.xhtml?dokumentId=497875\&poziomDo stepu=PUB\&indexAccordionPanel=-1 [dostęp: 1.08.2018 r.].

53 Zob. orzeczenie Wojewódzkiego Sądu Administracyjnego w Lublinie z dnia 6 kwietnia 2018 r., I SA/Lu 914/17, CBOSA. 
jest formą wprowadzenia pewnych ustawowych unormowań w zakresie umożliwienia formalnej współpracy spółdzielni socjalnych oraz innych podmiotów, do których można zaliczyć organizacje pozarządowe lub kościelne osoby prawne będące założycielami Centrów Integracji Społecznej, Warsztatów Terapii Zajęciowej, Klubów Integracji Społecznej oraz Zakładów Aktywności Zawodowej ${ }^{54}$. Poprzez konsorcjum należy w tym przypadku rozumieć umowę łączącą przynajmniej dwie strony, której celem jest realizacja określonego zadania gospodarczego. Zgodnie z opinią ustawodawcy przyjąć należy, iż jest to forma umowy nienazwanej, która nie jest ściśle zdefiniowana w przepisach prawa. Jej konstrukcja uzależniona jest od woli stron, które precyzyjnie zgodnie z obowiązującymi przepisami winny określić jej warunki, chociaż część badaczy przyznaje jej cechy umowy spółki cywilnej. Ich zdaniem przemawia za tym między innymi: brak utraty niezależności przez podmioty przystępujące do konsorcjum, wspólne ponoszenie zysków i odpowiedzialności oraz ryzyka, powołanie na czas określony i nieokreślony oraz brak posiadania osobowości prawnej ${ }^{55}$. Podobnie wypowiadają się na ten temat także inni autorzy wskazując jednak na to, iż to od woli stron zależy jak skonstruują umowę konsorcjum zawierając tam wszystkie elementy związane chociażby z odpowiedzialnością solidarną jego członków za niewykonanie zadania w wyznaczonym terminie ${ }^{56}$. Podobnie jest również w przypadku konsorcjum spółdzielczego, gdzie to strony decydują o konstrukcji umowy, choć jej podstawowe elementy zapisane są bezpośrednio w ustawie ${ }^{57}$. W związku z tym, iż definicja umowy konsorcjum spółdzielczego nie została bezpośrednio określona w ustawie przyjąć należy, iż jest to forma umowy nienazwanej, która jest kształtowana w oparciu o zasadę swobody zawierania umów zapisaną $\mathrm{w}$ art. 353 k.c. Z czasem z pewnością doczekamy się definiowania tej formy konsorcjum przez doktrynę - jak $\mathrm{w}$ innych przypadkach ${ }^{58}$.

54 Zob. art. 1 pkt 10 u.s.s.2017.

55 Zob. L. Stecki, Konsorcjum, Toruń 1994, s. 28.

56 Zob. M. Podleś, L. Siwik, Spótka cywilna w obrocie gospodarczym, Warszawa 2009, s. 16.

57 Zob. A. Chrząszcz, Konsorcjum w zamówieniach publicznych, „Przegląd Prawa Handlowego" 2013, nr 7, s. 45.

58 Zob. K. Muchowska-Zwara, Prawne problemy funkcjonowania konsorcjów uczestniczqcych w obrocie regulowanym przez prawo zamówień publicznych, Warszawa 2015, s. 2. 
Podstawowym celem istnienia konsorcjum spółdzielczego jest realizacja założonych zadań. Najważniejszym z nich jest zwiększenie potencjału ekonomicznego i społecznego zrzeszonych spółdzielni socjalnych. Ma to o tyle istotne znaczenie, iż sprzyja rozwojowi sektora i ograniczenia wykluczenia społecznego na terenie danej jednostki samorządu terytorialnego. Dzięki takiej formie współpracy spółdzielnie mogą nadto rozwijać wspólną sieć produkcji i dystrybucji. Sprzyjać to może specjalizacji poszczególnych członków konsorcjum zwłaszcza, gdy uczestniczą w nim inne - poza spółdzielniami socjalnymi - podmioty. Realizację celów może utrudniać fakt, iż konsorcjum spółdzielcze nie posiada osobowości prawnej, tym samym w przypadku sporów stronami są wszyscy jego uczestnicy ${ }^{59}$.

Poza celami głównymi konsorcjum spółdzielcze zobowiązuje się również realizować cele uzupełniające, choć przez ustawodawcę zostały one postawione na równi z ekonomicznymi. Wskazać tutaj należy na organizowanie wspólnych promocji działań gospodarczych i spółdzielczych oraz promowanie wspólnego znaku towarowego. Ma to służyć przełamywaniu barier i stereotypów występujących w stosunku do sektora spółdzielczości socjalnej i ekonomii społecznej. Łączne realizowanie tych celów powinno być sprecyzowane szczegółowo w umowie konsorcjum spółdzielczego.

Warunkiem zawiązania konsorcjum jest podpisanie przez strony właściwej umowy. Winna ona zawierać przede wszystkim elementy zawarte w przepisach prawa, ale strony mogą ją rozszerzyć o elementy niezbędne dla jego prawidłowego funkcjonowania ${ }^{60}$.

Najważniejszym elementem są cele zawarcia umowy. Powinny być one ściśle sprecyzowane, tak aby były one jasne dla każdego z podmiotów. Ogólne ich zapisanie utrudnia finalne wykazanie ich realizacji, co ma przełożenie na zakończenie całej umowy konsorcjum spółdzielczego.

Poza celami równie istotne jest oznaczenie zadań leżących po stronie konsorcjantów oraz jego skład. Ma to znaczenie w sytuacji, gdy do umowy przystąpią uczestnicy niebędący przedsiębiorcami. Wówczas należy

59 Zob. M. Czerwiński, Udziat konsorcjum w postępowaniu o udzielenie zamówienia publicznego na przykładzie Polski, Wielkiej Brytanii i Francji, „Przegląd Prawniczy Uniwersytetu im. Adama Mickiewicza" 6(2016), s. 314.

60 Zob. B. Król, K. Śnieżko, Wspótpraca przedsiębiorców w ramach umowy konsorcjum, „Geoinżynieria: Drogi, Mosty, Tunele” 2015, nr 1, s. 97. 
im przydzielić zadania, w których się specjalizują, tak aby nie dochodziło do sytuacji wycofania się podmiotu z realizacji danej umowy. Sprecyzowanie wymogów dotyczy również spółdzielni socjalnych. Te podmioty, które posiadają doświadczenie $\mathrm{w}$ danej działalności, powinny się zajmować swoją dziedziną, aby usprawnić wykonanie zadania. Nie oznacza, to bynajmniej, iż nie mogą się one podjąć nowych ról - wszystko w takim przypadku zależy jednak od tego, aby realizowały to wspólnie z parterem posiadającym stosowne doświadczenie. Podział zadań wymaga również wyznaczenia lidera konsorcjum. Jest on odpowiedzialny za koordynacje działań oraz kontakty z podmiotami zewnętrznymi, takimi jak chociażby administracja publiczna czy inni przedsiębiorcy. Taką rolę winien pełnić podmiot posiadający bogate doświadczenie i długi staż gospodarczy, bowiem to od niego zależy realizacja wszystkich celów ${ }^{61}$.

Zazwyczaj umowa konsorcjum spółdzielczego wymaga określenia czasu jej obowiązywania - będzie to najczęściej czas realizacji określonego zadania, mimo że prawo dopuszcza możliwość zawarcia jej na czas nieokreślony. Pozwala to także na wypróbowanie systemu zarządzania realizacją zadania, który jest odmienny niż ten występujący w spółdzielni socjalnej ${ }^{62}$.

W związku z tym, iż konsorcjum trwa przez określony czas, w umowie należy określić warunki przyjmowania, wykluczania lub występowania stron konsorcjum. Należy to zrobić we właściwy sposób, ponieważ ich niedookreślenie może prowadzić do zerwania umowy przez zleceniodawcę, a w konsekwencji do utraty środków finansowych. Tym samym środki finansowe zawarte $\mathrm{w}$ funduszu wzajemnościowym spółdzielni socjalnych mogą zostać zaprzepaszczone ${ }^{63}$.

Konsorcjum spółdzielcze może przystąpić do zamówień i ofert nieuregulowanych $\mathrm{w}$ ustawie o zamówieniach publicznych. Nie oznacza to bynajmniej, iż ustawodawca zablokował spółdzielniom socjalnym korzystanie ze wszystkich postępowań realizowanych w ramach zamówień publicznych. Warunkiem jest jednak fakt, iż muszą do takiego konsor-

61 Zob. A. Sobiech, Wspótpraca w ramach "wspólnego przedsięwzięcia" - wybrane problemy podatkowe, "Zeszyty Naukowe - Uniwersytet Szczeciński. Finanse, Rynki Finansowe, Ubezpieczenia" 2016, nr 5 (83), cz. 1, s. 131.

62 Zob. M. Starnawska, Między wspólnota a biznesem - system rządzenia w przedsiębiorstwie społecznym - studia przypadku, „Przegląd Organizacji” 2016, nr 1, s. 28.

63 Zob. A. Politaj, Państwowe fundusze celowe jako źródło wsparcia finansowego spótdzielni socjalnych w Polsce, „Nauki o Finansach” 2017, nr 1, s. 67. 
cjum przynależeć jedynie spółdzielnie socjalne, bowiem tylko one posiadają status przedsiębiorcy ${ }^{64}$.

Zdefiniowanie funduszu wzajemościowego jest ściśle powiązane z powołaniem do życia konsorcjum spółdzielczego. Na jego rzecz ma być przeznaczana określona część nadwyżki bilansowej - jednak ustawodawca nie zdecydował się na wskazanie, jaka minimalna wielkość jej części ma zostać $\mathrm{w}$ ten sposób zabezpieczona ${ }^{65}$. Takie rozwiązanie należy ocenić pozytywnie, bowiem to same władze spółdzielni decydują o jego utworzeniu, gdy przystępują lub tworzą konsorcjum spółdzielcze. Istotnym jest, iż jego bezpośrednim przeznaczeniem są cele, do jakich zostaje powołane samo konsorcjum. W takim przypadku Walne Zgromadzenie, powołując do życia ten fundusz, bezpośrednio zgadza się z wydatkowaniem wskazanych środków na konkretne zadania związane z działalnością gospodarczą i reintegracją środowiska spółdzielczego. To ono decyduje, jaka część nadwyżki bilansowej spółdzielni zostaje przeznaczona na ten konkretny cel. Może to następować w drodze konsultacji wewnątrz organizacji, co potwierdza, jakie znaczenie ma rola sposobu decydowania przecz członków organizacji ${ }^{66}$.

Wprowadzenie funduszu wzajemnościowego i instytucji konsorcjum spółdzielczego ma istotne znaczenie. Pozwala spółdzielniom socjalnym nie tylko integrować się, ale także nawiązywać współpracę z innymi organizacjami, co ma istotne znaczenie $\mathrm{w}$ zakresie zwalczania wykluczenia społecznego w gminie.

\section{Swoboda tworzenia funduszy przez władze spółdzielni sposobem stymulowania rozwoju organizacji}

Spółdzielnia socjalna podobnie jak każda organizacja spółdzielcza posiada swobodę tworzenia różnego rodzaju funduszy poza tymi zdefinio-

64 Zob. B. Bieńkowska, Spótdzielnie socjalne - szanse i bariery rozwoju przedsiębiorczości społecznej w Polsce, „Prace Naukowe Uniwersytetu Ekonomicznego we Wrocławiu” 2016, nr 450 , s. 40.

65 Zob. art. 10 ust. 1 pkt 3 ustawy z dnia 27 kwietnia 2006 r. o spółdzielniach socjalnych, tekst jednolity: Dz. U. z 2018 r. poz. 1205.

${ }_{66}$ Zob. M. Brzeziak, Nowe rozwiazania dla spótdzielni socjalnej, „ES.O.ES” 2017, nr 4, s. 4. 
wanymi jako obowiązkowe. Można je podzielić na fundusze ekonomiczne, pracownicze i społeczne ${ }^{67}$.

W przypadku funduszy ekonomicznych będą one stanowić odpowiednik funduszu inwestycyjnego. W ramach takich funduszy winny być wskazane zadania (z nazwy), które w ramach środków na nim zgromadzonych będą realizowane. Takie rozwiązanie świadczy o pełnej swobodzie Walnego Zgromadzenia, co do kierunku rozwoju gospodarczego danej organizacji. Tym samym fundusz na realizację projektów związanych z zakupem nowego sprzętu i urządzeń może być różny - w zależności od lokalizacji spółdzielni i kierunków działalności. Z punktu widzenia sprawozdania finansowego fundusze ekonomiczne, obok wyniku finansowego, stanowić będą istotne źródło informacji o działalności gospodarczej spółdzielni socjalnej, brane pod uwagę nie tylko przez administrację publiczną, ale również i przez partnerów, którymi nie zawsze będą inne spółdzielnie socjalne. Właściwa lokacja środków pozwoli spółdzielni nie tylko się rozwijać, ale także i pozyskiwać nowych kooperantów ${ }^{68}$. Fundusze ekonomiczne winny być oparte o długofalowe programy rozwoju organizacji. Podstawowym problemy w przypadku spółdzielni socjalnych jest jednak fakt, iż nie dysponują one zazwyczaj zdolnościami organizacyjnymi do przygotowania takich strategii. Tutaj istotną rolę mogą odegrać związki rewizyjne skupiające także inne rodzaje spółdzielni, które mogą przekazać - w drodze wzajemnego uczenia się organizacji - stosowną wiedzę i narzędzia ${ }^{69}$.

Dodatkowo zauważyć należy, iż spółdzielnia socjalna może stać się, jak każdy przedsiębiorca, stroną w postępowaniu sądowym czy administracyjnym. Tym samym władze spółdzielni, w ramach funduszy przeznaczonych na realizację celów gospodarczych, winny zdefiniować fundusz na pokrycie kosztów sporów sądowych prowadzonych z kontrahentami czy administracją publiczną. Wydatki z tego funduszu powinny być kierowane nie tylko na pomoc prawną, ale także poniesienie kosztów

67 Zob. B. Godlewska-Bujok, C. Miżejewski, Ustawa o spółdzielniach socjalnych. Komentarz, Warszawa 2016, s. 94.

68 Zob. Z. Firkowska-Jakobsze, J. Szwajcar, Istota oraz zasady prezentacji funduszy specjalnych w sprawozdaniu finansowym jednostki, [w:] Z. Luty, A. Łakomiak, A. Mazur (red.), Branżowe problemy rachunkowości i podatków, seria: Prace Naukowe Uniwersytetu Ekonomicznego we Wrocławiu, nr 373, Wrocław 2014, s. 36.

69 Zob. S. Juszczyk, R. Balina, E. Stola, J. Różyński, Fundusze udziałowe kluczowym narzędziem rozwoju bankowości spółdzielczej w Polsce, "Zeszyty Naukowe - Uniwersytet Szczeciński. Finanse, Rynki Finansowe, Ubezpieczenia" 2014, nr 65, s. 486. 
sądowych. Bowiem zgodnie z przyjętym orzecznictwem spółdzielnie socjalne, jako pełnoprawni przedsiębiorcy, nie mogą liczyć na ciągłe zwolnienia z kosztów sądowych lub bezpłatną pomoc pełnomocnika, które to są zarezerwowane jedynie dla szczególnych przypadków ${ }^{70}$.

W ramach funduszy społecznych, poza wyodrębnionym funduszem fakultatywnym związanym z reintegracją społeczną i zawodową członków i pracowników spółdzielni socjalnej, Walne Zgromadzenie może również zdecydować się na powołanie do życia funduszu integracyjnego. Z tych zasobów możliwe jest finansowanie wszelkich zadań obejmujących współpracę podmiotu z lokalną wspólnotą obejmującą nie tylko administrację samorządową, ale także organizacje pozarządowe. W ramach tych działań mogłyby być podejmowane działania związane z otwarciem się spółdzielni na potrzeby mieszkańców. Poprzez pomoc przy organizowaniu chociażby lokalnych imprez finansowanych $\mathrm{z}$ tych środków możliwe staje się upowszechnianie roli spółdzielni socjalnych oraz niwelowanie wykluczenia społecznego. Ponadto $\mathrm{z}$ takiego funduszu można prowadzić dofinansowanie spotkań w ramach realizacji akcji społecznych, w tym proekologicznych. Nie bez znaczenia pozostaje nadto fakt, iż na specjalne akcje władze spółdzielni socjalnej mogą wyasygnować dodatkowe środki tworząc odrębne fundusze. Mogą one obejmować chociażby środki na prowadzenie lokalnych zbiórek odzieży na rzecz wspierania osób defaworyzowanych ${ }^{71}$.

Fundusze pracownicze można wykorzystać do tworzenia funduszu stabilizującego wynagrodzenie. Z uwagi na sytuację sektora spółdzielczości socjalnej - związaną z ciągłą dynamiką zmian o charakterze gospodarczym oraz to, iż tego typu podmioty najczęściej są częścią sektora mikro i małych przedsiębiorstw prezentującego największe narażenia na zmiany koniunktury ekonomicznej - takie rozwiązanie jest właściwe. Pozwala zabezpieczyć wypłatę wynagrodzeń dla członków i pracowników takiej organizacji, którzy zazwyczaj przynależą do osób wykluczonych. Wypełnia to podstawową rolę spółdzielni, jaką jest danie powiązanym z nią osobom oraz ich najbliższym szansy na wyjście z ubóstwa dzięki zdobyciu zatrudnienia. Planowanie takiego funduszu winno zawierać wytyczne, w jakiej wielkości podmiot powinien przekazywać cześć nadwyżki bilan-

70 Zob. postanowienie Wojewódzkiego Sądu Administracyjnego w Lublinie z dnia 23 marca 2017 r., I SA/Lu 1033/16, CBOSA.

71 Zob. A. Englot, Rachunkowość spótdzielni socjalnej, Warszawa 2012, s. 39. 
sowej. W latach stabilizacji ekonomicznej powinna być ona zdecydowanie wyższa niż w przypadku okresów, kiedy przedsiębiorca posiadałby trudności finansowe. Należy również zauważyć, iż takie wsparcie mogą budować spółdzielnie dłuższe stażem na rynku lub spółdzielnie socjalne osób prawnych, których założyciel przeznaczy na ten cel stosowne środki. Niestety jak dotąd niewiele spółdzielni socjalnych może pochwalić się takim sposobem zabezpieczenia interesów pracownika ${ }^{72}$.

Decyzję o powołaniu do życia stosownych funduszy podejmuje Walne Zgromadzenie przy współpracy z innymi organizacjami spółdzielczymi, które mogą dopomóc w budowaniu długofalowej strategii. Warunkiem niezbędnym jednak do takich działań jest pozyskanie wiarygodnych danych o aktualnej sytuacji ekonomicznej podmiotu. $W$ tym zakresie istotną rolę do spełnienia ma Zarząd. W przypadku spółdzielni socjalnej w jego skład powinny wchodzić osoby nie tylko rozumiejące ideały ruchu, ale także posiadające doświadczenie $\mathrm{w}$ prowadzeniu działalności gospodarczej. Od ich decyzji zależy sytuacja ekonomiczna spółdzielni, a w konsekwencji - możliwość podejmowania dalszych działań o charakterze strategicznym. Zarząd, jako organ odpowiedzialny za reprezentowanie spółdzielni socjalnej, winien w swoich decyzjach kierować się przede wszystkim rachunkiem ekonomicznym oraz stosować odpowiednie narzędzia $\mathrm{w}$ zakresie zarządzania podmiotem nie zapominając jednak o innych celach związanych z reintegracją społeczną i zawodową ${ }^{73}$.

\section{Podsumowanie}

Spółdzielnia socjalna prowadzi swoją gospodarkę finansową w oparciu o opisane wyżej fundusze. Najważniejszym z nich - z punktu widzenia stabilizacji ekonomicznej działalności spółdzielni - pozostaje fundusz zasobowy. Jest on finansowany nie tylko z wkładów członków, ale także z bieżącej działalności spółdzielni. Zmniejszenie minimalnego wkładu z nadwyżki

72 Zob. R. Szarfenberg, Pozaekonomiczne funkcje spótdzielni socjalnych i ich realizacja. Proponowane wskaźniki i metody pomiaru, [w:] C. Żołędowski, M. Ołdak (red.), Spółdzielczość socjalna. Wybrane aspekty metodologiczne i porównawcze, Warszawa 2015, s. 99.

${ }^{73}$ Zob. J. Szpon, M. Kosobucka, P. Serej, Analiza funkcjonowania i zarządzania spółdzielnia socjalna w ujęciu konkurencyjności na lokalnym rynku, „Studia Zarządzania i Finansów Wyższej Szkoły Bankowej w Poznaniu" 2016, nr 10, s. 74. 
bilansowej z pułapu $40 \%$ do $20 \%$ stanowi krok w dobrym kierunku. Władze spółdzielni dzięki temu mogą przeznaczać środki na inne cele związane z działalnością ekonomiczną i społeczną. W związku z tym, iż podstawowym celem funduszu zasobowego jest zabezpieczanie interesów finansowych spółdzielni, środki nie mogą być przeznaczone na bieżącą działalność podmiotu. Obniżenie wartości pozwala na swobodę podejmowania decyzji przez władze spółdzielni, które w określonych przypadkach mogą podjąć uchwałę o zwiększeniu przeznaczonych na ten cel środków.

Analogiczne rozwiązanie ustawodawca zastosował również w przypadku funduszu fakultatywnego związanego z realizacją działań w zakresie reintegracji społecznej i zawodowej swoich członków. W tym przypadku obniżono wartość procentową nadwyżki bilansowej przeznaczonej na ten cel z 40\% do 30\%. Dzięki takiemu rozwiązaniu spółdzielnie socjalne mogą swobodnie kształtować działania związane z reintegracją zawodową i społeczną jej pracowników oraz członków. Obniżona wartość środków pochodząca z nadwyżki może być przeznaczona na rozwój gospodarczy jednostki.

Kształtowanie kierunków rozwoju gospodarczego spółdzielni jest tym bardziej efektywne, iż zdecydowano się na likwidację funduszu inwestycyjnego na rzecz dobrowolności tworzenia innych funduszy zadaniowych przeznaczonych na konkretne projekty zwiększające efektywność produkcji i świadczenia usług przez spółdzielnię socjalną. Pozytywnie przemawia za tym, również powołanie do życia funduszu wzajemnościowego, który pozwala na udział podmiotów spółdzielczości socjalnej w konsorcjach spółdzielczych. Dzięki nim organizacje te mogą nie tylko integrować się budując przewagę konkurencyjną, ale i współdziałać z sektorem pozarządowym.

Podsumowując, ewolucyjne zmiany w gospodarce finansowej spółdzielni należy ocenić pozytywnie. Swoboda pozostawiona w zakresie gospodarowania majątkiem spółdzielni przez ich członków daje możliwość ich dostosowania do potrzeb każdej organizacji i środowiska jej działania. Problemem może być jedynie brak świadomości po stronie władz spółdzielni w zakresie zarządzania podmiotem, ze względu na niepełną wiedzę na temat mechanizmów rynkowych i prawnych aspektów funkcjonowania spółdzielni, którą należy na bieżąco doskonalić.

Słowa kluczowe: spółdzielnia socjalna, fundusz zasobowy, fundusz celowy, fundusz wzajemnościowy 


\section{Bibliografia}

Bieńkowska B., Spółdzielnie socjalne - szanse i bariery rozwoju przedsiębiorczości społecznej w Polsce, „Prace Naukowe Uniwersytetu Ekonomicznego we Wrocławiu" 2016, nr 450, s. 35-45.

Błażejowska M., Funkcjonowanie podmiotów ekonomii społecznej na obszarach wiejskich na przykładzie spółdzielni socjalnych, "Zeszyty Naukowe Szkoły Głównej Gospodarstwa Wiejskiego w Warszawie - Problemy Rolnictwa Światowego" 2011, t. 11 (26), z. 4, s. 26-36.

Brzeziak M., Nowe rozwiązania dla spółdzielni socjalnej, „ES.O.ES” 2017, nr 4, s. 4-8.

Chrząszcz A., Konsorcjum w zamówieniach publicznych, „Przegląd Prawa Handlowego" 2013, nr 7, s. 41-47.

Czarkowski M., Spótdzielnie socjalne w Warszawie, „Ekonomia Społeczna” 2013, nr 3, s. 133-144.

Czerwiński M., Udział konsorcjum w postępowaniu o udzielenie zamówienia publicznego na przykładzie Polski, Wielkiej Brytanii i Francji, „Przegląd Prawniczy Uniwersytetu im. Adama Mickiewicza" 6(2016), s. 307-338.

Duraj J., Przesłanki powstania spółdzielni socjalnych w Polsce i zróżnicowanie przedmiotu ich działania, "Acta Universitatis Lodziensis” 2012, nr 272, s. 7-24.

Dworniak J., M. Pietrzak, Spółdzielczość mleczarska - specyfika ekonomiczna i rola rewizji finansowej w nadzorze korporacyjnym, "Studia Prawno-Ekonomiczne" 2014, t. 91, cz. 2, s. 53-71.

Englot A., Rachunkowość spółdzielni socjalnej, Warszawa 2012.

Firkowska-Jakobsze Z., J. Szwajcar, Istota oraz zasady prezentacji funduszy specjalnych w sprawozdaniu finansowym jednostki, [w:] Z. Luty, A. Łakomiak, A. Mazur (red.), Branżowe problemy rachunkowości i podatków, seria: Prace Naukowe Uniwersytetu Ekonomicznego we Wrocławiu, nr 373, Wrocław 2014, s. 34-45.

Godlewska-Bujok B., C. Miżejewski, Ustawa o spótdzielniach socjalnych. Komentarz, Warszawa 2016.

Gostomski E., B. Lepczyński, Znaczenie członkostwa w kształtowaniu bezpieczeństwa finansowego i funduszy własnych w polskich bankach spótdzielczych, "Zeszyty Naukowe - Uniwersytet Szczeciński. Finanse, Rynki Finansowe, Ubezpieczenia” 2018, nr 1 (91): Zarządzanie finansami, s. 405-417

Juszczyk S., R. Balina, E. Stola, J. Różyński, Fundusze udziałowe kluczowym narzędziem rozwoju bankowości spótdzielczej w Polsce, "Zeszyty Naukowe - Uniwersytet Szczeciński. Finanse, Rynki Finansowe, Ubezpieczenia" 2014, nr 65, s. 485-497.

Kawa M., Kuźniar W., Spótdzielnie socjalne jako instytucje odpowiedzialności społecznej, „Nierówności Społeczne a Wzrost Gospodarczy” 2016, z. 4, s. 389-400.

Król B., K. Śnieżko, Wspótpraca przedsiębiorców w ramach umowy konsorcjum, "Geoinżynieria: Drogi, Mosty, Tunele" 2015, nr 1, s. 96-97. 
Krzywda D., Fundusze własne spółdzielni mieszkaniowych jako przedmiot sprawozdawczości i rewizji finansowej, [w:] B. Micherda (red.), Sprawozdawczość i rewizja finansowa: uwarunkowania ekonomiczne, społeczne i regulacyjne, Kraków 2015, s. 203-214.

Miżejewski C., Przemiany prawa spótdzielczości socjalnej w Polsce, „Problemy Polityki Społecznej: Studia i Dyskusje" 2013, nr 1, s. 43-66.

Moskaluk-Łągiewczyk K., Status prawny spótdzielni socjalnych, „Folia Iuridica Wratislaviensis" 2012, t. 1, nr 1, s. 159-176.

Muchowska-Zwara K., Prawne problemy funkcjonowania konsorcjów uczestniczących w obrocie regulowanym przez prawo zamówień publicznych, Warszawa 2015.

Ostrowski R., Podział nadwyżki bilansowej w spółdzielni, „Mieszkanie i Wspólnota” 2012, nr 5, s. 14-16.

Pleśniak M., Reintegracyjna funkcja spółdzielni socjalnych, [w:] J. Blicharz, L. Zacharko (red.), Trzeci sektor i ekonomia społeczna. Uwarunkowania prawne. Kierunki działań, Wrocław 2017, s. 227-234.

Podleś M., L. Siwik, Spółka cywilna w obrocie gospodarczym, Warszawa 2009.

Politaj A., Państwowe fundusze celowe jako źródło wsparcia finansowego spótdzielni socjalnych w Polsce, "Nauki o Finansach” 2017, nr 1, s. 64-75.

Sklarz J., Model finansowania spótdzielni mieszkaniowych a ewidencja kosztów, "Studia Ekonomiczne" 2005, nr 33, s. 303-324.

Sobczak M., Reintegracja społeczno-zawodowa osób po 45 roku życia w spótdzielniach socjalnych, "Acta Universitatis Lodziensis” 2015, t. 312, nr 2, s. 173-194.

Sobczak M.J., Dwa światy spółdzielni socjalnych w Polsce, „Ekonomia Społeczna” 2016, nr 2, s. 7-19.

Sobiech A., Wspótpraca w ramach "wspólnego przedsięwzięcia” - wybrane problemy podatkowe, "Zeszyty Naukowe - Uniwersytet Szczeciński. Finanse, Rynki Finansowe, Ubezpieczenia" 2016, nr 5 (83), cz. 1, s. 129-139.

Starnawska M., Między wspólnotą a biznesem - system rządzenia w przedsiębiorstwie społecznym - studia przypadku, „Przegląd Organizacji” 2016, nr 1, s. 28-36.

Stecki L., Konsorcjum, Torun 1994.

Szarfenberg R., Pozaekonomiczne funkcje spółdzielni socjalnych i ich realizacja. Proponowane wskaźniki i metody pomiaru, [w:] C. Żołędowski, M. Ołdak (red.), Spótdzielczość socjalna. Wybrane aspekty metodologiczne i porównawcze, Warszawa 2015, s. 97-115.

Szpon J., M. Kosobucka, P. Serej, Analiza funkcjonowania i zarządzania spółdzielnia socjalna w ujęciu konkurencyjności na lokalnym rynku, „Studia Zarządzania i Finansów Wyższej Szkoły Bankowej w Poznaniu" 2016, nr 10, s. 71-84.

Ziobrowska J., Spółdzielnie socjalne jako przykład rozwoju przedsiębiorczości społecznej w Polsce, [w:] B. Kryk (red.), Gospodarka regionalna i międzynarodowa, t. 2, seria: Zeszyty Naukowe. Studia i Prace Wydziału Nauk Ekonomicznych i Zarządzania - Uniwersytet Szczeciński, nr 46, Szczecin 2016, s. 333-342. 
Zuba-Ciszewska M., Wpływ koncentracji kapitatu własnego na jego efektywność w wybranych spótdzielniach mleczarskich w Polsce w latach 2003-2012, "Zeszyty Naukowe Szkoły Głównej Gospodarstwa Wiejskiego w Warszawie. Ekonomika i Organizacja Gospodarki Żywnościowej" 2015, nr 109, s. 107-121.

Zuba J., M. Zuba-Ciszewska, Wptyw kapitatu własnego na rentowność i bezpieczeństwo finansowe wybranych spótdzielni mleczarskich w Polsce, „Roczniki Naukowe Stowarzyszenia Ekonomistów Rolnictwa i Agrobiznesu" 2014, z. 2, s. 310-315. Zych J., Księgi rachunkowe a zarządzanie spótdzielnia mieszkaniowa, [w:] P. Lenik (red.), Zarzadzanie w sektorach prywatnym oraz publicznym, seria: Prace Naukowo-Dydaktyczne Państwowej Wyższej Szkoły Zawodowej im. Stanisława Pigonia w Krośnie, z. 70, Krosno 2016, s. 411-436.

Żbik W. (red.), Jak przygotować spótdzielnię socjalna do lustracji, seria: Biblioteka Spółdzielczości Socjalnej, t. 9, Warszawa 2015.

\section{CHANGES IN THE FINANCIAL STRUCTURE OF SOCIAL COOPERATIVES IN POLAND}

\section{Summary}

Social cooperatives are important element of social economy in Poland. The main objectives of this organization are social and vocational reintegration. They are financed by membership fees and balance surplus which is basic part of cooperatives economy. The balance surplus is being divided between cooperative founds. Its supports finance security and economical development of social cooperatives at social and economical level. In the last year legislator gave possibility to create different founds by Social Cooperative General Assemble as for example those which support social cooperatives integration in the local market. More details reader will find in the article.

Key words: social cooperative, balance surplus, cooperative founds

\section{ИЗМЕНЕНИЯ В ФИНАНСОВОЙ ЭКОНОМИКЕ ОБЩЕСТВЕННОГО КООПЕРАТИВА В ПОЛЬШЕ}

\section{Резюме}

Социальный кооператив - это вид предпринимателя, занимающийся предпринимательской деятельностью и выполняющий задачи в области социальной и профессиональной реинтеграции своих членов и работников. Эти виды деятельности финансируются за счет средств предприятия, по- 
лученных за счет собственного вклада их членов и излишка баланса, полученного предприятием в ходе операций. Основной фонд - это ресурсный фонд, обеспечивающий финансовые требования внешних организаций. Социальный кооператив также создает дополнительный фонд, связанный с выполнением уставных задач. В последнее время законодатель предоставил этим организациям большую свободу в области финансовой деятельности за счет сокращения суммы обязательных средств, расходуемых на вышеуказанные средства, и введения фонда взаимности и целевых фондов для реализации конкретных экономических проектов. В статье читатель найдет более широкое описание их влияния на развитие кооператива.

Ключевые слова: социальный кооператив, ресурсный фонд, фонд специального назначения, взаимный фонд 
